\title{
3.5 GHz Rectangular Patch Microstrip Antenna with Defected Ground Structure for 5G
}

\author{
DHATU PARAGYA, HARTONO SISWONO
}

\author{
Department of Electrical Engineering, Faculty of Industrial Technology \\ Gunadarma University, Jakarta, Indonesia \\ Email: paragya.md@gmail.com
}

Received 17 Maret 2019 | Revised 20 April 2019 | Accepted 30 November 2019

\begin{abstract}
ABSTRAK
Pada penelitian ini telah dilakukan perancangan dan implementasi antena mikrostrip untuk aplikasi generasi kelima (5G) pada frekuensi $3.5 \mathrm{GHz}$. Parameter yang diinginkan berdasarkan pada posisi kebijakan publik Huawei, posisi kebijakan publik Qualcomm, dan artikel $3^{\text {rd }}$ Generation Partnership Project (3GPP) Rel-15. Antena mikrostrip memiliki bandwidth yang sempit, oleh karena itu beberapa modifikasi digunakan, yaitu teknik proximity coupled dan defected ground structure (DGS). Tahap pertama adalah menghitung dimensi awal antena, kemudian disimulasikan menggunakan HFSS Ansoft. Simulasi dimulai dari simulasi dimensi awal, menambahkan teknik proximity coupled, dan penerapan DGS hingga parameter antena yang diinginkan tercapai. Aktivitas pengukuran dilakukan setelah simulasi dan optimasi telah selesai dikerjakan. Hasil dari pengukuran, gain bertambah menjadi $6.6 \mathrm{~dB}$, bandwidth berkurang sebesar $65.2 \mathrm{MHz}$, Voltage Standing Wave Ratio (VSWR) dan return loss masing-masing 1.31 dan -17.436 dB.
\end{abstract}

Kata kunci: antena mikrostrip, proximity coupled, DGS, 5G, 3.5 GHz

\begin{abstract}
This research has performed the design and implementation of microstrip antenna for fifth generation (5G) application, at frequency $3.5 \mathrm{GHz}$. The desired parameters are based on Huawei public policy position, Qualcomm public policy position, and Rel-15 $3^{\text {rd }}$ Generation Partnership Project (3GPP) article. Since microstrip antenna has narrow bandwidth, some modification are conducted, namely proximity coupled feeding and defected ground structure (DGS). The first stage is calculating the initial dimension of the antenna, finally the antenna is simulated and optimized. The simulation starts from simulating the initial dimension, then applying the proximity coupled feeding, after that employing the DGS until the desired antenna is achieved. The final stage is fabricate the antenna based on simulation then measure it. The measurement results show that the gain is increased to $6.6 \mathrm{~dB}$, the bandwidth is reduced by $65.2 \mathrm{MHz}$, the Voltage Standing Wave Ratio (VSWR) and return loss are 1.31 and $-17.436 d B$.
\end{abstract}

Keywords: microstrip antenna, proximity coupled, DGS, 5G, $3.5 \mathrm{GHz}$ 


\section{INTRODUCTION}

The fifth generation (5G) is the latest generation of cellular mobile communications. It succeeds the fourth generation (4G) with the Long Term Evolution (LTE) and Worldwide Interoperability for Microwave Access (WiMax), the third generation (3G) Universal Mobile Telecommunications System (UMTS) and second-generation (2G) Global System for Mobile communications (GSM) systems. 5G performance targets high data rate, reduced latency, energy saving, cost reduction, higher system capacity, and massive device connectivity. For instance, for the downlink (DL), the experienced data rate of up to $50 \mathrm{Mbps}$ are expected outdoor and 1 Gbps indoor (5GLAN), and half of these values for the uplink (UL), with the target for user plane latency, should be $4 \mathrm{~ms}$ for UL, and $4 \mathrm{~ms}$ for DL (3GPP, 2019). As 5G still on progress, there is no fix regulation in Indonesia, expected to be announced in 2020 or 2021 (PERTIWI, 2018).

However, some institutions already have major parameters and specification requirement for this next-gen communication, such as $3^{\text {rd }}$ Generation Partnership Project (3GPP) that has already finished the first phase. Also, some big companies have already published the specification for their future devices that will use $5 \mathrm{G}$ technology later, such as Huawei and Qualcomm, as pioneers for $5 G$ patents in east and west respectively (Qualcomm, 2017), (Huawei, 2017). Figure 1 shows the frequency aspect for the $5 \mathrm{G}$ technology according to the 3GPP Rel-15 on 5G New Radio (NR) of two frequency ranges which are FR1 being sub-6 $\mathrm{GHz}$ range (450 - $6000 \mathrm{MHz}$ ) and FR2 being the millimeter wave (mmWave) range (24250 $52600 \mathrm{MHz}$ ) (3GPP, 2019).

Huawei also notes that, as the first steps, it highly recommend that the countries allocate $3300-3800 \mathrm{MHz}$ or a portion of it and make it available for 5G with consistent timelines and regulatory frameworks, i.e., frequency arrangements and emission masks. It recommends that at least $100 \mathrm{MHz}$ of contiguous bandwidth from this band allocated to each 5G network. The frequencies for $5 \mathrm{G}$ are divide into three groups, that is low frequencies, medium frequencies, and high frequencies (Huawei, 2017). The design of microstrip patch antenna is a singlelayer consist generally of four parts, i.e., the patch, ground plane, substrate, and feeding part. The physical size of a microstrip antenna is small. However, the electrical size measured in the wavelength is not so small. The most commonly employed microstrip antenna is a rectangular patch (Paul \& Sultan, 2013).

Microstrip patch antennas have more advantages and better prospects compared to the conventional antennas, such as lighter in weight, low in volume, cost, profile, and smaller in dimension, as well as ease of fabrication and conformity. Moreover, the microstrip patch antennas can provide frequency agility, broad bandwidth, feedline flexibility and beam scanning omnidirectional patterning (Bisht, Saini, Prakash, \& Nautiyal, 2014).

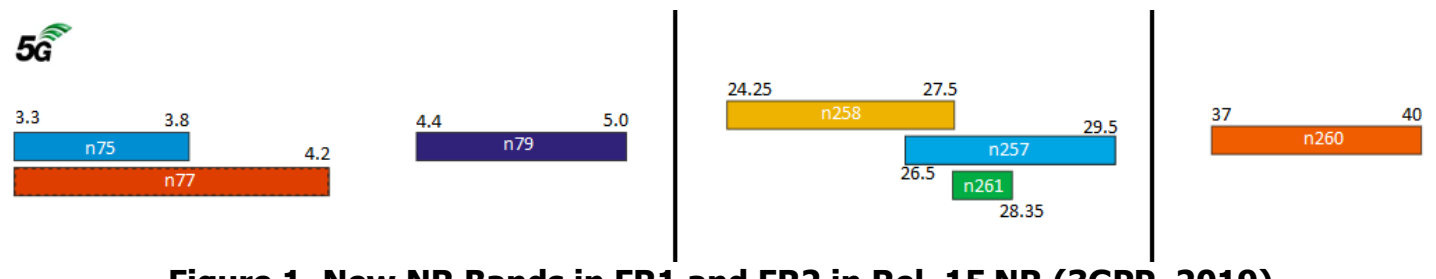

Figure 1. New NR Bands in FR1 and FR2 in Rel. 15 NR (3GPP, 2019) 


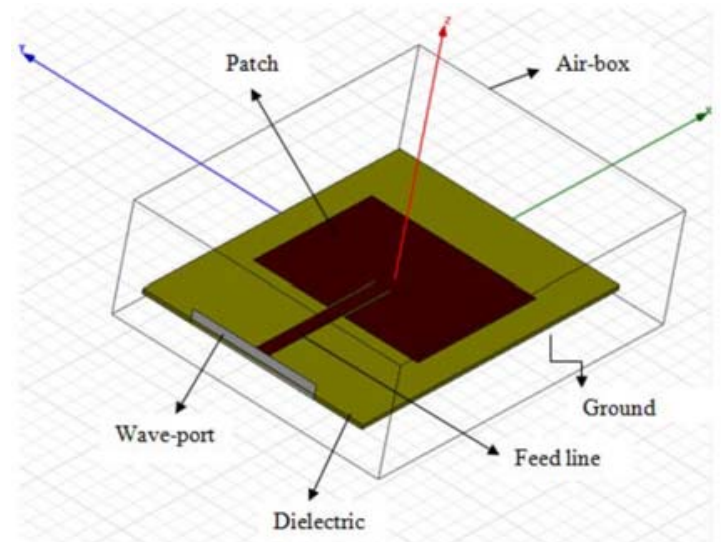

Figure 1. Structure of microstrip antenna (Mathur, Vats, \& Agarwal, 2015)

There are also some disadvantages such as narrow bandwidth, low gain, generate unwanted radiation because of its unification technique and low efficiency. To overcome the disadvantages, we can use several approaches, such as changing the feedline and making a defected ground plane.

\section{ANTENNA DESIGN}

\subsection{Calculation the Size of Patch}

The formula used for designing the width of a patch antenna (W) are as (Paul \& Sultan, 2013)

$$
W=\frac{c}{2 f \sqrt{\frac{\varepsilon_{r}+1}{2}}}
$$

where $f$ is the middle frequency, $\varepsilon_{r}$ being material relative constants, $c$ being the speed of light, and $h$ being substrate thickness are $3500 \mathrm{MHz}, 4.4,3 \times 10^{8} \mathrm{~m} / \mathrm{s}$, and $1.6 \mathrm{~mm}$, respectively. For $\frac{W}{h}>1$, the effective dielectric constant $\left(\varepsilon_{\text {reff }}\right)$ is defined by (Paul \& Sultan, 2013)

$$
\varepsilon_{\text {reff }}=\frac{\varepsilon_{r}+1}{2}+\frac{\varepsilon_{r}-1}{2}\left(\frac{1}{\sqrt{1+12 h / W}}\right)
$$

The electrical length of a patch antenna is greater than the physical. This normalized extension in length is calculated using (Paul \& Sultan, 2013)

$$
\Delta L=0.412 h \frac{\left(\varepsilon_{r e f f}+0.3\right)\left(\frac{W}{h}+0.264\right)}{\left(\varepsilon_{r e f f}-0.258\right)\left(\frac{W}{h}+0.8\right)}
$$

The actual length of a patch antenna (L) calculated using (Paul \& Sultan, 2013)

$$
L=\frac{c}{2 f \sqrt{\varepsilon_{\text {reff }}}}-2 \Delta L
$$

\subsection{Determining the Size of Feedline}

The feeding channel used in this paper has the impedance value equal to $50 \Omega$ calculated by

$$
\frac{W o}{h}=5.7961\left(\varepsilon_{r}^{-0.95}\right)
$$


where $W_{o}$ is the feedline width. From the Equation (1) - (5) the initial design of microstrip antenna single patch is shown by Table 1 as well as Figures 3 and 4. Table 1 shows the initial size of the antenna for the simulation. Figure 3 shows the substrate where the yellow area is the patch and the feedline. Figure 4 depicts the antenna ground plane and the antenna design.

Table 1. Microstrip Antenna Size for Simulation

\begin{tabular}{|c|c|}
\hline The Size of Patch $(\boldsymbol{W} \boldsymbol{x} \boldsymbol{L})$ & $26.08 \times 18.98 \mathrm{~mm}$ \\
\hline The Substrate Area $(W \mathbf{x} \mathbf{~ L s})$ & $50 \times 40 \mathrm{~mm}$ \\
\hline The Size of Ground $(\boldsymbol{W} \boldsymbol{g} \boldsymbol{L} \boldsymbol{g})$ & $50 \times 40 \mathrm{~mm}$ \\
\hline The Width of Feedline $\mathbf{5 0} \boldsymbol{\Omega}\left(\boldsymbol{w}_{\boldsymbol{f}}\right)$ & $2.27 \mathrm{~mm}$ \\
\hline The Length of Feedline $\mathbf{5 0 \Omega ( \boldsymbol { l } _ { \boldsymbol { f } } )}$ & $20 \mathrm{~mm}$ \\
\hline
\end{tabular}

\subsection{Initial Simulation Results}

The calculation results of the above design using Ansoft HFSS 15.0 shown in Table 2 and Figures 5 and 6 . As shown in Table 2, some of the desired parameters have not been achieving yet. The bandwidth and working frequency, which are still far from the desired, also needs to improve the other parameters. Figure 5 shows that the bandwidth achieved from the simulation is $0.1392 \mathrm{GHz}$ or $139.2 \mathrm{MHz}$ when the return loss is $-16.32 \mathrm{~dB}$. Furthermore, the working frequency at $-10 \mathrm{~dB}$ is nowhere near $3.4-3.6 \mathrm{GHz}$. Figure 6 shows that the VSWR is 1.3603. It is required to modify the antenna dimension to achieve the desired parameters.

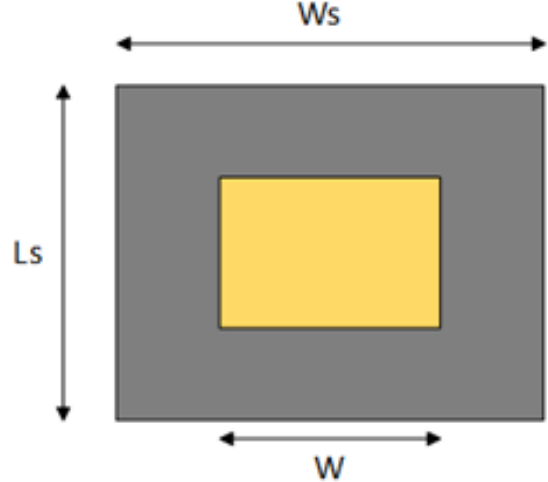

(a)

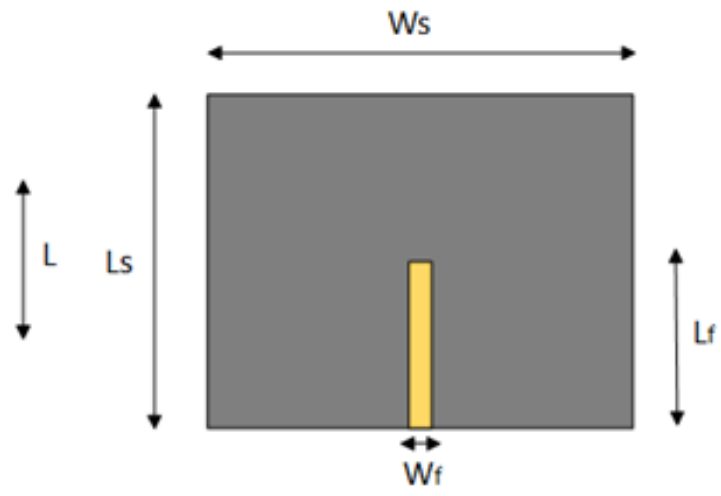

(b)

Figure 3. (a) Visualization of Antenna Patch and (b) Feedline

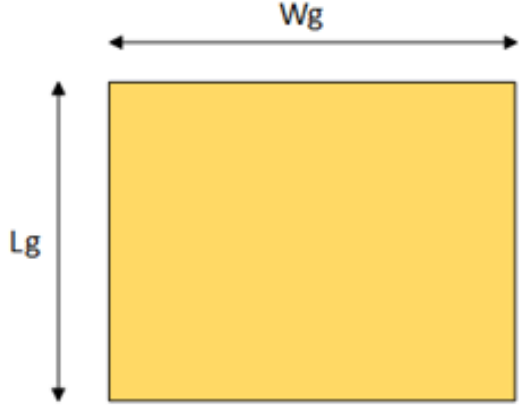

(a)

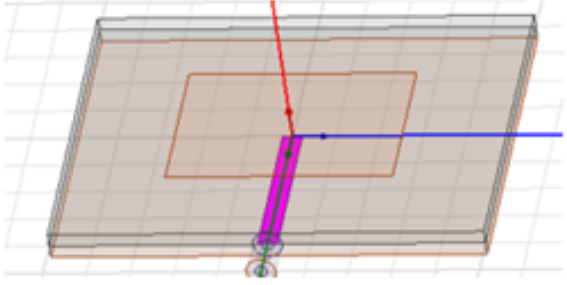

(b)

Figure 4. (a) Visualization of Antenna Ground and (b) Design on HFSS Ansoft 15 
Table 2. Comparison of Simulation Results and Desired Parameters

\begin{tabular}{|c|c|c|}
\hline Parameters & Simulation Result & Desired Parameters \\
\hline Return Loss & $-16.32 \mathrm{~dB}$ & $\leq-10 \mathrm{~dB}$ \\
\hline Working Frequency & $3324.8-3464.0 \mathrm{MHz}$ & $3400-3600 \mathrm{MHz}$ \\
\hline Bandwidth & $139.2 \mathrm{MHz}$ & $200 \mathrm{MHz}$ \\
\hline VSWR & 1.3603 & $\leq 1.9$ \\
\hline Gain & $3.6544 \mathrm{~dB}$ & Maximum $15 \mathrm{~dB}$ \\
\hline
\end{tabular}
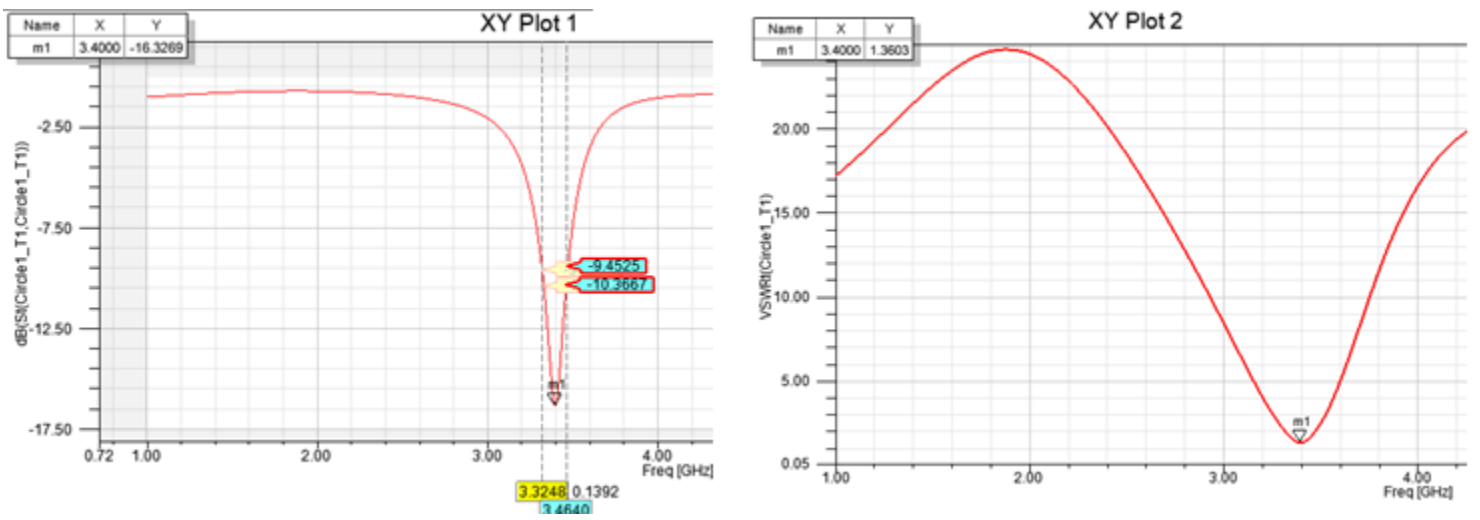

Figure 2. Simulation Results of the Working Frequency, Return Loss, and VSWR
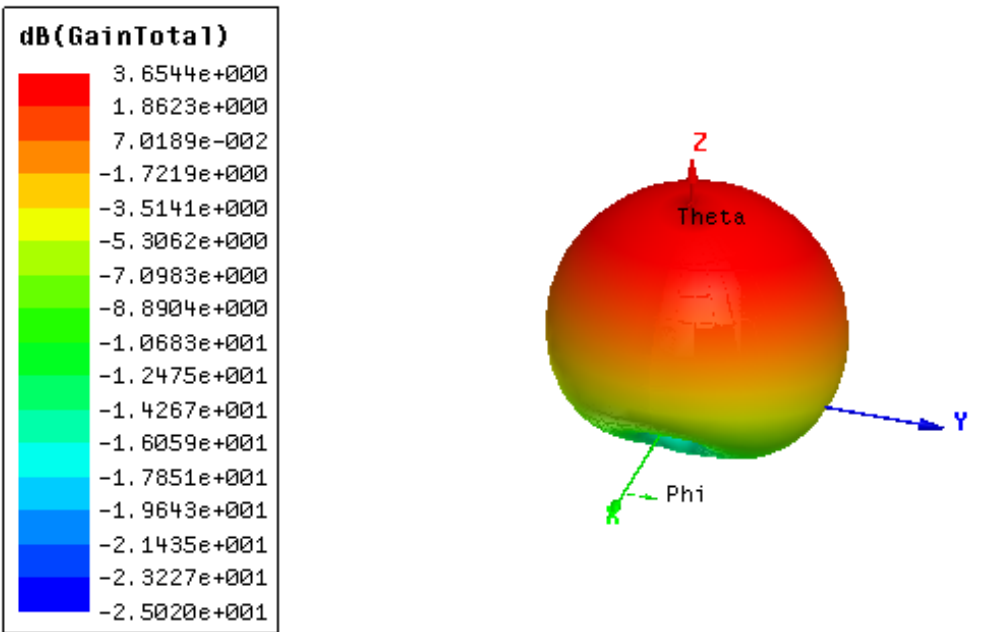

Figure 3. Simulation Results of Radiation Pattern and Gain

\section{ANTENNA OPTIMIZATION AND MEASUREMENT RESULTS}

\subsection{Changing Patch Size \& Feedline Length}

For optimization, there are several modifications to the antenna dimensions. The first step is modifying the patch size. Table 3 shows the effects of changing the dimension of the patch. According to Table 3, the working frequency is close to the desired parameters. The second step is modifying the length of the feedline, shown in Table 4. 
Paragya and Siswono

Table 3. Effects in Modifying the Dimension of the Patch

\begin{tabular}{|c|c|c|c|c|c|}
\hline $\begin{array}{c}\text { Patch Size } \\
(\mathbf{m m})\end{array}$ & $\begin{array}{c}\text { Return Loss } \\
\mathbf{( d B )}\end{array}$ & $\begin{array}{c}\text { Working Frequency } \\
\mathbf{( M H z )}\end{array}$ & $\begin{array}{c}\text { Bandwidth } \\
(\mathbf{M H z})\end{array}$ & VSWR & $\begin{array}{c}\text { Gain } \\
\mathbf{( d B )}\end{array}$ \\
\hline $\begin{array}{c}W=19.98 \\
\mathrm{~L}=26.08\end{array}$ & -38.466 & $3159.5-3346.7$ & 187.3 & 1.0515 & 2.714 \\
\hline $\begin{array}{c}W=18 \\
\mathrm{~L}=26\end{array}$ & -36.8453 & $3468.4-3658.3$ & 189.9 & 1.0292 & 3.9812 \\
\hline $\begin{array}{c}W=17.8 \\
\mathrm{~L}=26\end{array}$ & -32.43 & $3504.2-3692.8$ & 188.6 & 1.067 & 4.0091 \\
\hline $\begin{array}{c}W=18.8 \\
\mathrm{~L}=26\end{array}$ & -44 & $3341.5-3532.6$ & 191.1 & 1.0127 & 3.7851 \\
\hline $\begin{array}{c}W=18.4 \\
\mathrm{~L}=26.2\end{array}$ & -42.605 & $3400.9-3592.2$ & 191.3 & 1.0155 & 3.996 \\
\hline
\end{tabular}

Table 4. Effects in Modifying the Length of the Feedline

\begin{tabular}{|c|c|c|c|c|c|}
\hline $\begin{array}{c}\text { Feedline } \\
\text { Length Size } \\
(\mathbf{m m})\end{array}$ & $\begin{array}{c}\text { Return } \\
\text { Loss } \\
\mathbf{( d B )}\end{array}$ & $\begin{array}{c}\text { Working } \\
\text { Frequency } \\
\mathbf{( M H z}\end{array}$ & $\begin{array}{c}\text { Bandwidth } \\
\mathbf{( M H z )}\end{array}$ & VSWR & $\begin{array}{c}\text { Gain } \\
\mathbf{( d B )}\end{array}$ \\
\hline 18 & -28.2044 & $3357.9-3563.7$ & 205.8 & 1.0809 & 3.9635 \\
\hline 16 & -33.6172 & $3322.5-3519.0$ & 196.5 & 1.0426 & 3.9489 \\
\hline 17 & -31.4864 & $3336.2-3542.0$ & 205.8 & 1.0548 & 3.9848 \\
\hline 16.5 & -32.811 & $3331.2-3537.9$ & 206.7 & 1.0968 & 3.9526 \\
\hline 16.3 & -37.7945 & $3327.4-3430.8$ & 203.4 & 1.0561 & 3.9725 \\
\hline 17.4 & -30.3301 & $3341.6-3547.5$ & 205.9 & 1.0628 & 3.9359 \\
\hline 17.5 & -28.9186 & $3346.2-3553.0$ & 206.8 & 1.0821 & 3.9789 \\
\hline 17.8 & -29.009 & $3351.2-3557.4$ & 206.2 & 1.0735 & 3.9652 \\
\hline 17.6 & -29.5720 & $3350.4-3556.4$ & 206 & 1.0687 & 3.9808 \\
\hline
\end{tabular}

\subsection{Changing Substrate Size}

From Table 4, the best length for the feedline is $17.5 \mathrm{~mm}$. However, the working frequency is shifts a little. The next step is to reduce the overall dimension of the antenna, i.e., the ground plane and the substrate. The first dimension is $50 \times 40 \mathrm{~mm}$ and then changed to $40 \times 30 \mathrm{~mm}$. The result is that it shifts the working frequency to $3327.3-3495.5 \mathrm{MHz}$, reduces the bandwidth to $169.2 \mathrm{MHz}$, return loss is $-13.3654 \mathrm{~dB}$ and VSWR is 1.55 . It is because the dimension $40 \times 30 \mathrm{~mm}$ leads the parameters changed too much. Then modify the dimension to $45 \times 35 \mathrm{~mm}$. Hence, Table 5 shows the results.

Table 5. Effects in Modifying the Substrate Dimension

\begin{tabular}{|c|c|c|c|c|c|}
\hline $\begin{array}{c}\text { Substrate Size } \\
(\mathbf{m m})\end{array}$ & $\begin{array}{c}\text { Return Loss } \\
\mathbf{( d B})\end{array}$ & $\begin{array}{c}\text { Working Frequency } \\
(\mathbf{M H z})\end{array}$ & $\begin{array}{c}\text { Bandwidth } \\
(\mathbf{M H z})\end{array}$ & VSWR & $\begin{array}{c}\text { Gain } \\
(\mathbf{d B})\end{array}$ \\
\hline $45 \times 35$ & -26.2841 & $3315.1-3536.3$ & 221.2 & 1.13 & 3.6151 \\
\hline
\end{tabular}

With this modification, we achieve the desired parameters. However, the working frequency still shifts. Hence, we modify the dimension of the patch and the length of the feedline. Table 6 shows the effects in modifying the patch dimension and the length of the feedline with $45 \mathrm{x}$ $35 \mathrm{~mm}$ substrate. We achieve the desired working frequency when the patch dimension is 18 $x 26.2 \mathrm{~mm}$, and the length of the feedline is $15.2 \mathrm{~mm}$. 
Table 6. Effects in Modifying the Feedline and Patch Size

\begin{tabular}{|c|c|c|c|c|c|}
\hline $\begin{array}{c}\text { Patch \& Feedline Size } \\
(\mathbf{m m})\end{array}$ & $\begin{array}{c}\text { Return } \\
\text { Loss } \\
(\mathbf{d B})\end{array}$ & $\begin{array}{c}\text { Working } \\
\text { Frequency } \\
(\mathbf{M H z})\end{array}$ & $\begin{array}{c}\text { Bandwidth } \\
\mathbf{( M H z )}\end{array}$ & VSWR & $\begin{array}{c}\text { Gain } \\
(\mathbf{d B})\end{array}$ \\
\hline $\begin{array}{c}\mathrm{W}=18.2 ; \mathrm{L}=26.2 ; \\
\mathrm{Lf}=15\end{array}$ & -25.446 & $3358.2-3579$ & 220.8 & 1.1129 & 3.6713 \\
\hline $\begin{array}{c}\mathrm{W}=18 ; \mathrm{L}=26.2 ; \mathrm{Lf}= \\
15\end{array}$ & -26.185 & $3388.2-3613.1$ & 224.9 & 1.1032 & 3.7256 \\
\hline $\begin{array}{c}\mathrm{W}=18 ; \mathrm{L}=26.2 ; \\
\mathrm{Lf}=15.2\end{array}$ & -27.307 & $3388.2-3615.9$ & 227.8 & 1.0931 & 3.7253 \\
\hline
\end{tabular}

\subsection{Applying DGS on Ground Plane}

Implementing Defected Ground Structure (DGS) in microstrip patch results in improves the antenna bandwidth. Practically bandwidth obtained using DGS is up to $100 \mathrm{MHz}$ Along with bandwidth, other parameters such as the uniform current distribution, beamwidth, return loss, reflection coefficient, VSWR, are also improved. The final step of the optimization is modifying the ground plane with DGS. Figure 7 shows the experimental DGS used in the simulation. It should note that Table 7 shows the effect of modifying the ground plane of the antenna.

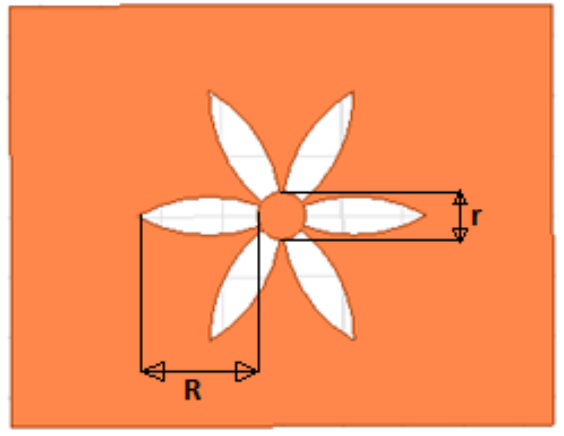

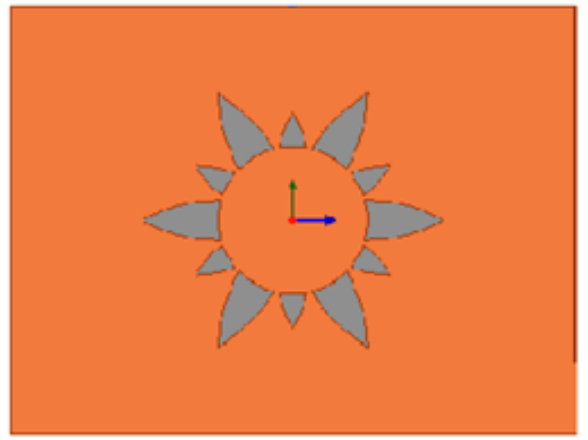

b

Figure 7. (a)(b) Experimental Defected Ground Structure (Weng, Guo, Shi, \& Chen, 2008)

Table 7. Effects of Applying DGS on Ground Plane

\begin{tabular}{|c|c|c|c|c|c|}
\hline $\begin{array}{c}\text { DGS (R) and } \\
(\mathbf{r})\end{array}$ & $\begin{array}{c}\text { Return } \\
\text { Loss } \\
(\mathbf{d B})\end{array}$ & $\begin{array}{c}\text { Working } \\
\text { Frequency (MHz) }\end{array}$ & $\begin{array}{c}\text { Bandwidth } \\
(\mathbf{M H z})\end{array}$ & VSWR & $\begin{array}{c}\text { Gain } \\
(\mathbf{d B})\end{array}$ \\
\hline $\begin{array}{c}\text { DGS }(\mathrm{a}) \\
\mathrm{R}=9 ; r=1\end{array}$ & -25.9021 & $3252.6-3502.5$ & 249.9 & 1.1209 & 3.3389 \\
\hline $\begin{array}{c}\text { DGS }(a) \\
R=9 ; r=2\end{array}$ & -28.8809 & $3294.7-3543.2$ & 248.5 & 1.0859 & 3.4357 \\
\hline $\begin{array}{c}\text { DGS }(a) \\
R=12 ; r=1\end{array}$ & -25.3558 & $3204.8-3461.6$ & 256.8 & 1.1141 & 3.1575 \\
\hline $\begin{array}{c}\text { DGS }(a) \\
R=12 ; r=2\end{array}$ & -23.0672 & $3133.2-3390.2$ & 257 & 1.1543 & 2.8696 \\
\hline $\begin{array}{c}\text { DGS (b) } \\
R=9 ; r=6\end{array}$ & -39.4964 & $3362.3-3604.4$ & 242 & 1.0214 & 3.6137 \\
\hline $\begin{array}{c}\text { DGS }(b) \\
R=9 ; r=5.5\end{array}$ & -36.5635 & $3323-3572.5$ & 249.5 & 1.032 & 3.5060 \\
\hline $\begin{array}{c}\text { DGS (b) } \\
R=9 ; r=7\end{array}$ & -29.7706 & $3394.9-3628.1$ & 233.2 & 1.0671 & 3.661 \\
\hline
\end{tabular}




\subsection{Antenna Final Size and Simulation Results}

Based on Table 7, the last result is satisfied with the desired parameters. With the working frequency close to the desired parameters, it achieves better VSWR and positive gain. The following Table 8 as well as Figure 8 and Figure 9 are complete specifications and simulation results of Rectangular Patch Microstrip Antenna with Proximity Coupled Feeding Technique and Defected Ground Structure. Table 8 shows the final size of the antenna design that we will fabricate. Furthermore, Figures 8 shows the simulation result of the final design, i.e., the antenna working frequency, return loss, and VSWR. Next, Figures 9 shows the radiation pattern and gain of the antenna.

Table 8. Microstrip Antenna Final Design

\begin{tabular}{|c|c|}
\hline Patch Size (W $\mathbf{x ~ L )}$ & $26.2 \times 18 \mathrm{~mm}$ \\
\hline Substrate Area (Wg $\mathbf{x ~ L g )}$ & $45 \times 35 \mathrm{~mm}$ \\
\hline The Width of Feedline (Wf) & $3.06 \mathrm{~mm}$ \\
\hline The Length of Feedline (Lf) & $17 \mathrm{~mm}$ \\
\hline Inner radius of DGS & $7 \mathrm{~mm}$ \\
\hline Outer radius of DGS & $9 \mathrm{~mm}$ \\
\hline
\end{tabular}
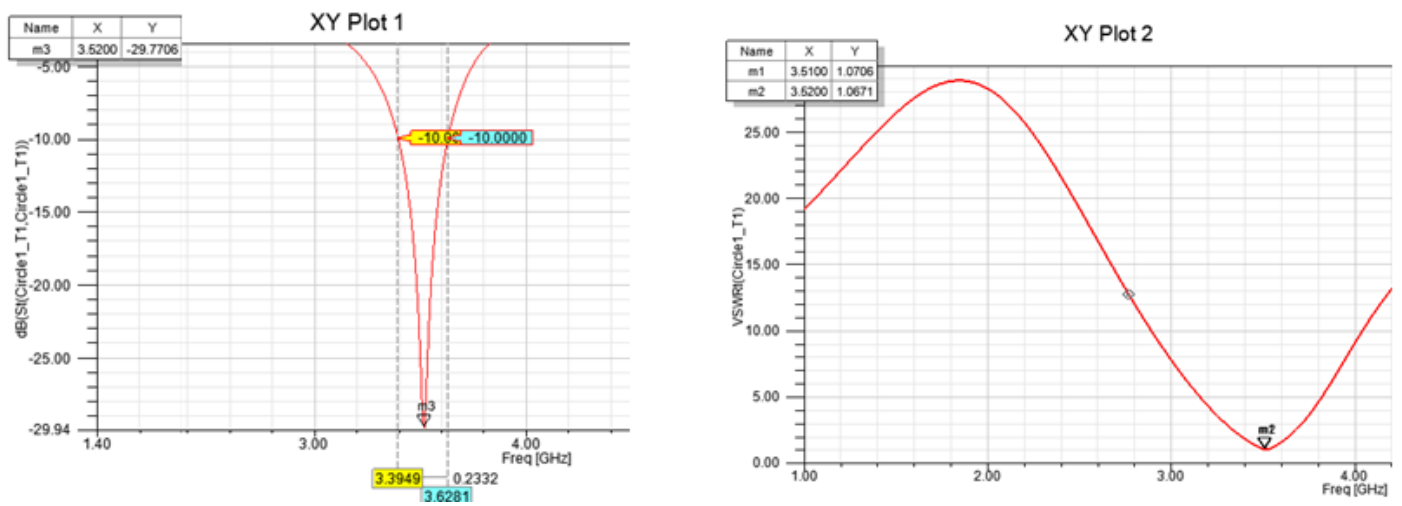

Figure 4. Final Simulation Results of the Working Frequency, Return Loss, and Voltage Standing Wave Ratio (VSWR)
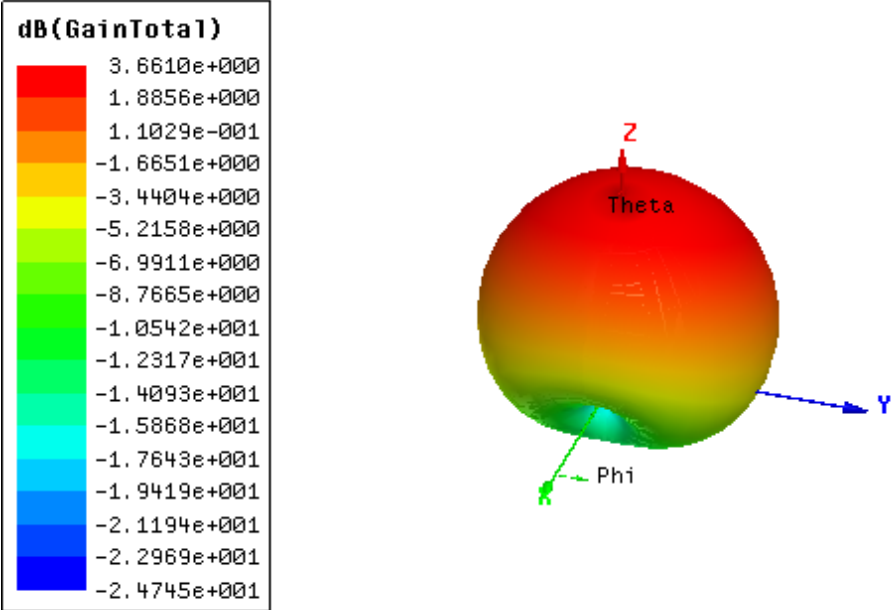

Figure 5. Final Simulation Results of Radiation Pattern and Gain 


\subsection{Fabricated Antenna}

Based on the simulation design using HFSS Ansoft 15.0 software, the fabricate antenna shown in Figures 10 and 11. We fabricate the antenna on a double layer printed circuit board (PCB) that consists of two PCB. The first PCB or substrate etching for the patch of the antenna. And, the second substrate for the feedline and the ground plane of the antenna. Figures 10 and 11 show the etching result. Then, combine the two substrates, in this case, the first and second substrate with duct tape. On the feedline area, a connector soldered.

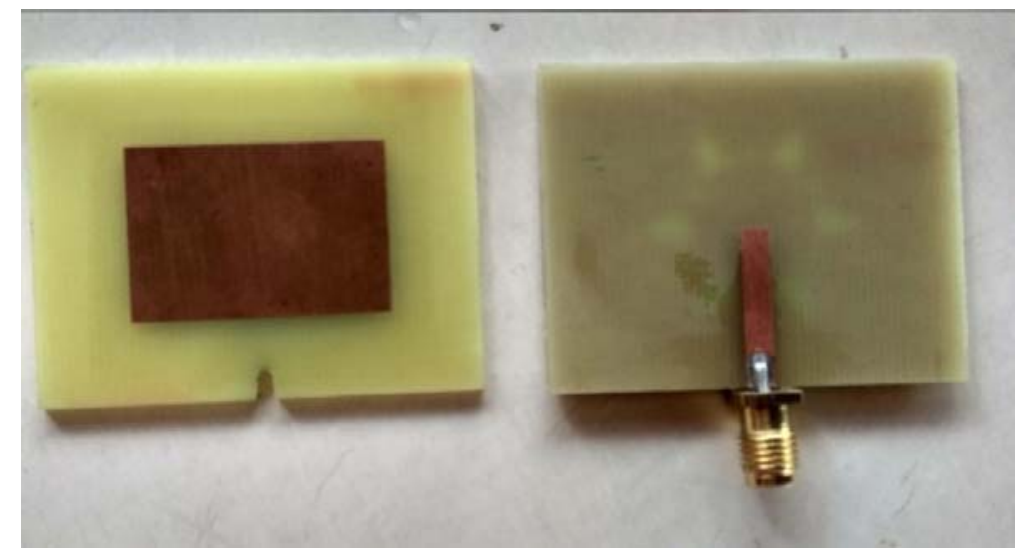

Figure 6. The First and Second Substrate of Antenna

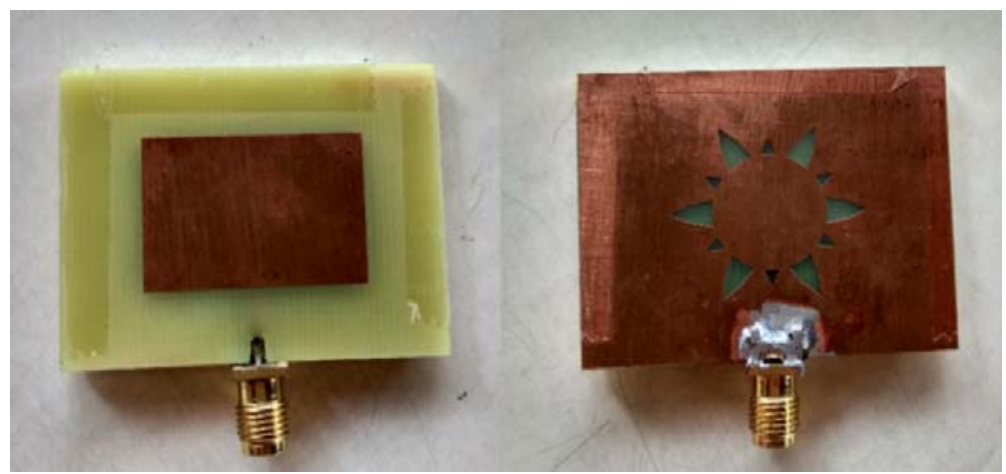

Figure 7. Antenna Front View and Back View

\subsection{Antenna Measurement Results}

Figures 12 and 13 show the antenna parameters that are measured. Figure 12.(a) shows the antenna working frequency and return loss results. While Figure 12.(b) shows the antenna VSWR results. The return loss is $-17.436 \mathrm{~dB}$, with the working frequency is at $3.417-3.585$ $\mathrm{GHz}$. Hence, the bandwidth becomes $168 \mathrm{MHz}$, and the middle frequency is $3.5 \mathrm{GHz}$. The antenna VSWR measurement result are (1) the VSWR is of 1.919 for $3.417 \mathrm{GHz}$, (2) the VSWR is of 1.925 for $3.585 \mathrm{GHz}$, and (3) the VSWR is of 1.310 for $3.5 \mathrm{GHz}$. The antenna parameter uses the VSWR at the middle frequency.

The difference between the simulation and the measurement results are occurred by some several factors as follows. (1) The fabricated antenna shows that there is reduces in thickness. There is a trail of sandpapering the substrates, hence the thickness of the antenna is reduced. The change of thickness affects the bandwidth of the antenna. In addition, (2) the fabricated antenna manufactured conventionally by etching a double layer printed circuit board (PCB). This method also can cause the thickness of the substrates to decrease. Moreover, (3) when the two substrates combined, there is little gap near the connector. 


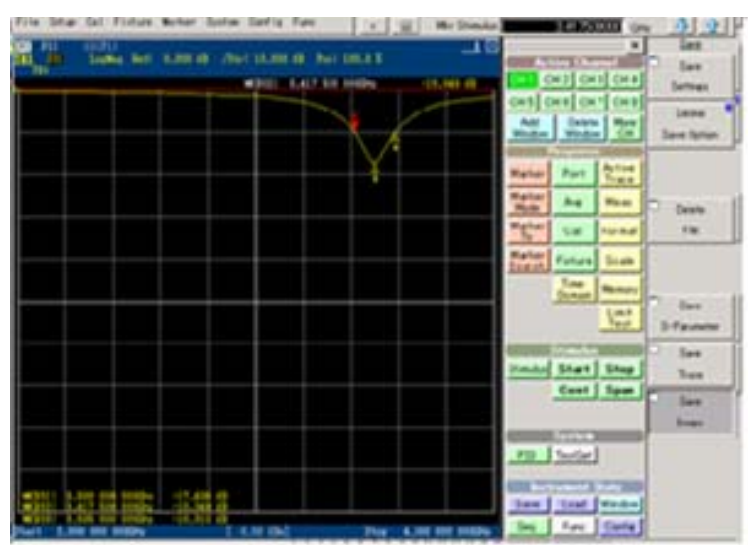

(a)

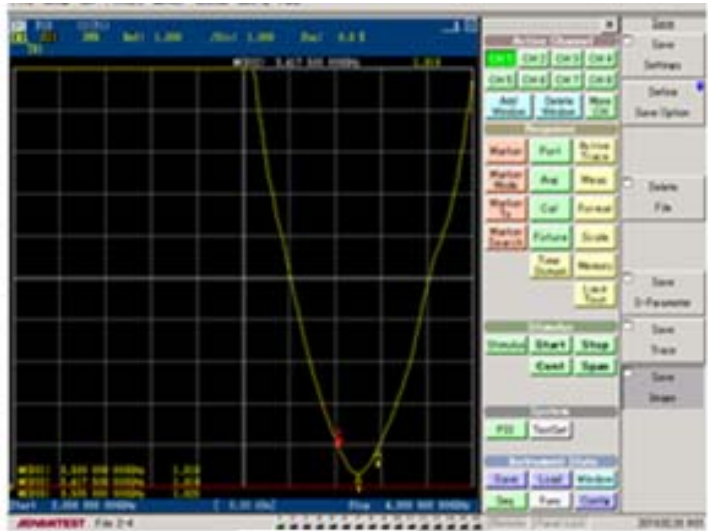

(b)

Figure 8. (a) Return Loss and Working Frequency Results; (b) VSWR Results

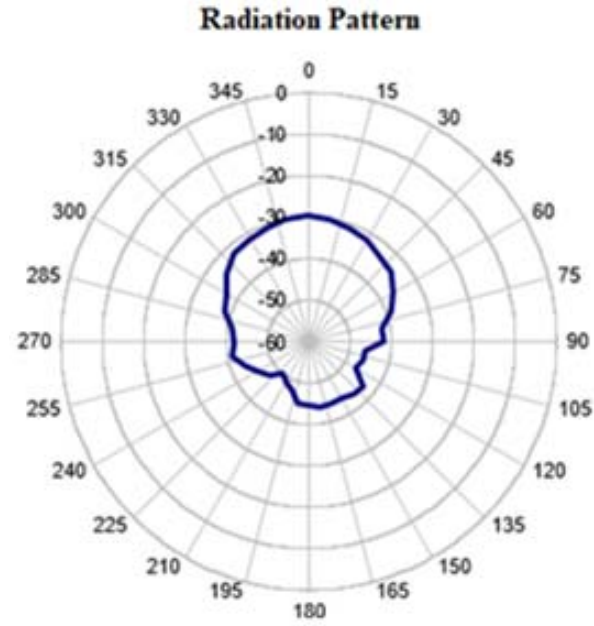

(a)

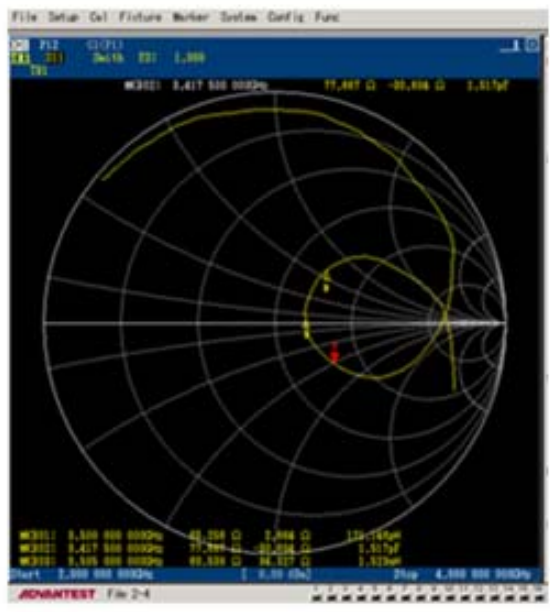

(b)

Figure 9. (a) Radiation Pattern; (b) Impedance Measurements Results

Figure 13.(a) shows the radiation pattern that achieved from measurement and processed with Microsoft Excel. While Figure 13.(b) shows the impedance of the antenna at 3.417, 3.5, and $3.585 \mathrm{GHz}$ are $77.667,65.256$, and $68.538 \Omega$, respectively. The one used as the input impedance of the antenna is the impedance at the middle frequency. The impedance of the antenna at $3.417,3.5$, and $3.585 \mathrm{GHz}$ are $77.667,65.256$, and $68.538 \Omega$, respectively. It should note that the one used as the input impedance of the antenna is the impedance at the middle frequency.

To measure the magnitude of the gain on the antenna, we can use the equation expressed as

$$
G=P 1-P 2+G_{\text {Reff }}
$$

where $P_{1}$ is the gain value of two identical horn antenna, $P_{2}$ is the gain value when microstrip antenna tested as a receiver, and $\mathrm{G}_{\text {Reff }}$ is the gain value of the reference antenna. Referring to Equation (6) with $\mathrm{P}_{1}$ of $-33 \mathrm{~dB}$, the value of $\mathrm{P}_{2}$ of $-29.51 \mathrm{~dB}$ and the reference antenna gain value of $10.1 \mathrm{~dB}$, the antenna gain value is $6.61 \mathrm{~dB}$. Table 9 shows the final simulation and measurement results. It shows the simulation and measurement results are not in accordance, but both still satisfy the desired parameters. 
Table 9. Simulation and Measurement Results

\begin{tabular}{|c|c|c|}
\hline Parameter & Simulation & Measurement \\
\hline Return Loss $(\mathrm{dB})$ & -29.77 & -17.436 \\
\hline Working Frequency $(\mathrm{GHz})$ & $3.395-3.628$ & $3.417-3.585$ \\
\hline Bandwidth (MHz) & 233.2 & 168 \\
\hline VSWR & 1.0671 & 1.31 \\
\hline Input Impedance $(\Omega)$ & 50 & 65.256 \\
\hline Gain (dB) & 3.661 & 6.61 \\
\hline Radiation Pattern & Directional & Directional \\
\hline Polarization & Linear & Linear \\
\hline
\end{tabular}

\section{CONCLUSION}

There are some differences between the simulation and the measurement results, but the parameters are considered well enough, as it is satisfied the desired parameters. It is because the bandwidth decreased by a significant amount. The results in this research are that the VSWR increased by 0.242 , the impedance increased by $15.256 \Omega$, the gain increased by $3 \mathrm{~dB}$, and the return loss changed to $-17.436 \mathrm{~dB}$. The VSWR, return loss, and gain are satisfie the desired parameters. Also, the bandwidth satisfies both the public position of Huawei and Qualcomm. Huawei advises that the bandwidth for $5 \mathrm{G}$ at least $100 \mathrm{MHz}$. While, Qualcomm advises that for mid-band 5G, the bandwidth is $150 \mathrm{MHz}$. Finally, the simulation and the measurement results show that the antenna is in accordance with the desired parameters. It expected that hopefully, the antenna is useful for $5 \mathrm{G}$ applications.

\section{REFERENCES}

3GPP. (2019). TR 21.915 V0.6.0. Sophia Antipolis: 3rd Generation Partnership Project (3GPP). Bisht, S., Saini, S., Prakash, D. V., \& Nautiyal, B. (2014). Study The Various Feeding Techniques of Microstrip Antenna Using Design and Simulation Using CST Microwave Studio. International Journal of Emerging Technology and Advanced Engineering, 4(9), 318324.

Huawei. (2017). 5G Spectrum Public Policy Position. Shenzen: Huawei.

Mathur, M., Vats, A., \& Agarwal, A. (2015). A New Design Formulae for Feed Line Dimensions. Institute of Electrical and Electronics Engineers, 2(1), 105-110.

Paul, L. C., \& Sultan, N. (2013). DESIGN, SIMULATION AND PERFORMANCE ANALYSIS OF A LINE FEED RECTANGULAR MICRO-STRIP PATCH ANTENNA. International Journal of Engineering Sciences \& Emerging Technologies, 4(2), 117-126. 
PERTIWI, W. K. (2018, 12 12). tekno.kompas.com. Retrieved from www.kompas.com: https://tekno.kompas.com/read/2018/12/12/13320067/regulasi-5g-baru-dibikin2020-indosat-sebut-sangat-terlambat

Qualcomm. (2017). Spectrum for $4 G$ and 5G. San Diego: Qualcomm Technologies, Inc.

Weng, L. H., Guo, Y. C., Shi, X. W., \& Chen, X. Q. (2008). AN OVERVIEW ON DEFECTED GROUND. Progress In Electromagnetics Research $B, 1(7), 173-189$. 